МОСИН Василий Иванович - кандидат философских наук, доцент; генеральный директор Тульского социологического центра (300001, Россия, г. Тула, ул Гармонная, 28 оф. 39; толіn55@ bk.ru)

\title{
РЕЙТИНГ 100 ВЛИЯТЕЛЬНЫХ ТУЛЯКОВ - 2017: СТАБИЛЬНОСТЬ И ПЕРЕМЕНЫ
}

Аннотация. В статье автор рассказывает о ежегодных рейтингах влиятельных персон в Тульской обл. и о тенденциях изменений в позициях политических, экономических, культурных, творческих деятелей. Ключевые слова: рейтинг, влияние, политики, доверие, руководители

2005 г. работает исследовательская программа «Проблемы социокультурной эволюции России и ее регионов» под эгидой одноименного научно-координационного совета секции философии, социологии, политологии, психологии и права Отделения общественных наук РАН (председатель совета - членкорреспондент РАН Н.И. Лапин), при поддержке РГНФ/РФФИ. В рамках программы подготовлены социокультурные портреты более 20 регионов России, на их основе издан коллективный труд ${ }^{1}$.

В Тульской обл. в рамках изучения социокультурной эволюции региона для лучшей ориентации населения вот уже более 10 лет составляются ежегодные рейтинги политических, экономических, культурных, творческих деятелей: с 2004 г. - «Кто из туляков внес наибольший вклад с социально-экономическое развитие Тульской области»; с 2012 г. - «100 наиболее влиятельных туляков»; с 2011 г. - ежегодное вручение премии «Тульский бизнес». В последние годы популярность получил рейтинг женщин-предпринимателей «Бизнес под каблуком». Эти рейтинги пользуются заслуженным доверием среди туляков, размещаются на сайте Российского общества социологов. Благодаря рейтингам, туляки получили возможность четко ориентироваться в политической, экономической и социокультурной жизни региона.

Наибольшей популярностью пользуется рейтинг «100 наиболее влиятельных туляков», сокращенно Топ-100, который создается Тульским социологическим центром совместно с «Тульским бизнес-журналом» и информационным агентством «Тульские новости». Данный рейтинг составляется с учетом мнения экспертов, среди которых - социологи, бизнесмены, представители СМИ, политики. Материалы о методике составления рейтинга публиковались в общенациональном научно-политическом журнале «Власть» [Мосин 2013; Мосин 2014].

В начале 2018 г. был опубликован 6-й по счету Топ-100. Возглавляет рейтинг губернатор Тульской обл. Алексей Дюмин. Должность губернатора предоставляет много властных рычагов, и А. Дюмин это успешно использует в руководстве Тульской обл., благодаря чему она занимает хорошее место в Центральном федеральном округе. За время работы губернатором он подобрал в целом профессиональную команду, и результаты ее работы туляки ощущают на себе, что и отразили эксперты, поставив А. Дюмина, как и в прошлом году, на 1-е место. Его окружение практически сохранило свои позиции в рейтинге: кто-то немного поднялся, кто-то опустился, но это обычная практика в политике.

В первой половине списка Топ-100 новых лиц почти нет. Сюда смогли войти только 3 человека: А. Стариков - руководитель следственного управления

\footnotetext{
1 Атлас модернизации России и ее регионов: социоэкономические и социокультурные тенденции и проблемы (сост. и отв. ред. Н.И. Лапин). М.: Весь Мир. 2016. 360 с.
} 
Следственного комитета РФ по Тульской области (19-е место); А. Третьяков министр здравоохранения Тульской обл. (36-е место); В. Чапкин - генеральный директор ПАО «НПО «Стрела» (47-е место). Во 2-й части списка новичков больше - 14. В большинстве своем это те, кто недавно начал свою политическую или экономическую карьеру, но уже добился определенных результатов.

Из списка Топ-100 выбыли в основном вышедшие в отставку или ушедшие на заслуженный отдых политики, бизнесмены, руководители.

Особенно хочется сказать о «долгожителях» Топ-100. Это хорошо известные в регионе руководители и политики. Следует отметить несколько наиболее известных имен: А. Зиновьев - руководитель Управления ФСБ по Тульской обл.; Н. Воробьев - генеральный директор ООО «Газпром межрегионгаз Тула»; А. Козлов - прокурор Тульской обл.; Ю. Андрианов - председатель правительства Тульской обл., первый заместитель губернатора; Ю. Агафонов - президент Тульской торгово-промышленной палаты; Б. Сокол - владелец ОХК «Шекиноазот»; Е. Авилов - глава администрации г. Тулы; В. Жерздев - глава администрации МО г. Новомосковск; С. Галкин - начальник УМВД России по Тульской обл.; С. Харитонов - председатель областной Думы 6-го созыва; И. Панченко - член Совета Федерации ФС РФ от Тульской обл.; В. Толстой - советник президента РФ по вопросам культуры; В. Суханов - руководитель УФНС России по Тульской обл.; В. Шерин - заместитель председателя правительства Тульской обл.; владыка Алексий, митрополит Тульский и Ефремовский; Е. Дронов - генеральный директор АО «АК «Туламашзавод»; А. Шестаков - управляющий Тульским отделением Сбербанка; И. Курилов генеральный директор ПАО «Тульский оружейный завод»; А. Сорокин - заместитель губернатора Тульской обл.; Ю. Елагин - руководитель Управления Федеральной антимонопольной службы по Тульской обл.; В. Афонский - депутат Государственной думы 7-го созыва; Ю. Вепринцева - министр молодежной политики Тульской обл.

Анализируя результаты последнего Топ-100, можно сказать, что в 2017 г. резких изменений в политической, экономической и социокультурной жизни Тульской обл. не произошло.

По данной методике стали создаваться рейтинги Топ-100 в Калужской, Владимирской и Орловской обл.

\section{Список литературы}

Мосин В.И. 2013. Рейтинг 100 самых влиятельных туляков: методика составления. - Власть. № 5. С. 191-192.

Мосин В.И. 2014. Рейтинг 100 влиятельных туляков - 2013: без сюрпризов не обошлось. - Власть. № 8. С. 148-149.

\section{RATING OF 100 INFLUENTIAL RESIDENTS OF TULA - 2017: STABILITY AND CHANGES}

Abstract. The article discusses the annual ratings of influential people in the Tula Region and trends of changes in the positions of political, economic, cultural and creative figures.

Keywords: rating, influence, politics, trust, leaders 